\begin{tabular}{lll}
\hline Volume : 1 & No : 2 November 2016 & ISSN : 2502 - 7069 \\
\hline
\end{tabular}

\title{
PENGARUH PENGEMBANGAN KEPROFESIAN DAN KEPEMIMPINAN KEPALA SEKOLAH TERHADAP KINERJA GURU SEKOLAH DASAR NEGERI SE-KECAMATAN LABUAPI KABUPATEN LOMBOK BARAT
}

Oleh :

\author{
Lu'luin Najwa1, Aos Santosa Hadiwijaya2, Dadi Setiadi3 \\ Universitas Mataram \\ S2apunram.najwa@gmail.com \\ setiarasyid@gmail.com \\ aos_santosa@yahoo.com
}

\begin{abstract}
Abstrak : Penelitian ini bertujuan untuk mengetahui pengaruh pengembangan keprofesian dan kepemimpinan kepala sekolah terhadap kinerja guru. Penelitian ini adalah penelitian expost facto. Sampel penelitian ini berjumlah 66 orang guru Pegawai Negeri Sipil (PNS) Sekolah Dasar Negeri tersertifikasi di Kecamatan Labuapi yang ditentukan dengan teknik Simple Random Sampling. Instrumen pengumpulan data berupa kuesioner. Analisis data menggunakan teknik analisis deskriptif, analisis regresi dan analisis korelasi parsial. Hasil penelitian menunjukkan: 1) Pengembangan keprofesian berpengaruh terhadap kinerja guru dilihat dari nilai $t$ hitung $>t$ tabel yaitu 7,066 $>2,000$, koefisien determinasi sebesar 43,8\% dan koefisien korelasi parsial sebesar 0,597 ; 2) Kepemimpinan kepala sekolah berpengaruh terhadap kinerja guru dilihat dari nilai t hitung $>$ t tabel yaitu 3,811 >2,000, koefisien determinasi sebesar 18,5\%, dan koefisien korelasi parsial sebesar 0,$285 ; 3$ ) Pengembangan keprofesian dan kepemimpinan kepala sekolah berpengaruh terhadap kinerja guru dilihat dari hasil $\mathrm{F}$ hitung $>$ Ftabel yaitu 28,568 $>3$,13, dan koefisien determinasi sebesar 47,6\%. Hal ini berarti bahwa pengembangan keprofesian yang dilakukan guru setelah sertifikasi dan motivasi dari kepala sekolah melalui kepemimpinannya berpengaruh pada unjuk kerja guru dalam melaksanakan aktivitas pembelajaran. Oleh karena itu, peningkatan kinerja guru dapat diupayakan melalui pengembangan keprofesian setelah sertifikasi dan peningkatan fungsi kepemimpinan kepala sekolah.
\end{abstract}

Kata Kunci: pengembangan keprofesian, kepemimpinan kepala sekolah, kinerja guru.

Abstract : This research aims to discover the effects of professional development and the principal leadership towards the teachers' performance. This study is an expost facto study. The research sample consisted of 66 government employee teachers of Elementary School at Labuapi sub district was established using the simple random sampling technique. The data were collected by questionnaire. The data were analyzed using the descriptive analysis, regression analysis, and partial correlation analysis. The results of the study show that: 1) 
The professional development influences teacher's performance by thitung $>t$ tabel which is 7,066 $>2,000$ with coefficient determination is 43,8\%, and coeffiecient partial correlation 0,597. 2) The principal leadership influences on teacher's performance by $t$ hitung $>t$ tabel which is 3,811 > 2,000 with coeffiecient determination is 18,5\%, and coeffiecient partial correlation 0,285.3) The professional development and principal leadership influence teacher's performance by $F$ hitung $>$ Ftabel or 28,568 > 3,13, and coeffiecient determination is 47,6\%. It means the professional development after certification and motivation by their leadership influence the increase of teacher's performance.in learning activities. Thus, the increasing of teacher's performance can be efforted with the professional development after certification and the increasing of principal leadership fungtion.

Keywords: professional development, principal leadership, teacher's performance.

\section{PENDAHULUAN}

Pendidikan memiliki peranan yang besar dalam proses kemajuan suatu bangsa. Salah satu komponen pendidikan yang memiliki peran besar dalam upaya mencapai tujuan pendidikan adalah seorang guru. Definisi guru menurut Peraturan Pemerintah (PP) RI No. 74 Tahun 2008 tentang Guru dan Dosen Pasal 1 ayat 1 adalah pendidik professional dengan tugas utama mendidik, mengajar, membimbing, mengarahkan, melatih, menilai, dan mengevaluasi peserta didik pada pendidikan anak usia dini jalur pendidikan formal, pendidikan dasar dan menengah.

Kinerja guru professional menjadi salah satu penentu tinggi rendahnya prestasi belajar siswa maupun mutu pendidikan. Rendahnya pencapaian Indonesia dalam bidang pendidikan menjadi hal yang perlu diperhatikan lebih dalam. Pendidikan dapat berjalan dengan optimal jika komponenkomponen di dalamnya bekerja dengan optimal. Oleh karena itu, untuk meningkatkan mutu pendidikan di Indonesia, diperlukan peningkatan pada semua komponen pendidikan.

Rendahnya kualitas guru di Indonesia dijelaskan oleh Syahwal Gultom Kepala Badan Pengembangan Sumber Daya Manusia Pendidikan dan Kebudayaan (BPSDMPK) dilihat dari masih banyak guru yang tidak lulus uji kompetensi dan sertifikasi, buruknya hasil ujian nasional, dan masih banyak guru yang belum memenuhi standar kuelifikasi.

Upaya pemerintah Indonesia dalam membenahi rendahnya kualitas guru salah satunya adalah melalui program sertifikasi. Program ini merupakan bentuk perhatian dan perjuangan pemerintah mewujudkan tujuan pendidikan nasional melalui penghargaan dan pengakuan terhadap status guru sebagai profesi. Sertifikasi merupakan standardisasi bagi profesi guru, bahwa seorang guru professional yang memiliki kualifikasi dan kompetensi layak memberikan layanan pendidikan bagi peserta didik. Hal ini sesuai dengan amanat Undang-undang No. 14 Tahun 2005 tentang Guru dan Dosen bahwa pemerintah mengatur standardisasi guru (kualifikasi dan kompetensi).

Perhatian kepada guru merupakan salah satu upaya yang dapat dilakukan untuk mencapai tujuan pendidikan. Upaya perbaikan mutu pendidikan nasional dilakukan mulai dari memperbaiki proses belajar mengajar 
yang dilakukan guru. Jika perbaikan terhadap kualitas aktivitas pembelajaran dilakukan secara konsisten dengan mengedepankan mutu proses pembelajaran di kelas, maka secara perlahan masalah yang terkait dengan pendidikan dapat dikurangi.

Selain pengaturan terhadap standardisasi guru, pemerintah juga mengatur mengenai pembinaan dan pengembangan guru. Peraturan Menteri Negara Pemberdayaan Aparatur Negara dan Reformasi Birokrasi Nomor 16 Tahun 2009 tentang jabatan fungsional guru dan angka kreditnya mengatur tentang Program Pengembangan Keprofesian Berkelanjutan (PKB). Kegiatan PKB ini diarahkan untuk meningkatkan keprofesian guru dan memenuhi tuntutan di masa depan terkait dengan pelaksanaan tugas dan kewajibannya dalam memberikan layanan pendidikan yang berkualitas bagi peserta didik.

Sejak diberlakukannya sertifikasi pada tahun 2005, hingga saat ini dampak positif bagi peningkatan mutu pendidikan dari program ini belum terlihat jelas. Tujuan dari sertifikasi guru yaitu untuk mencapai tujuan pendidikan dan mempertahankan profesionalisme guru belum seutuhnya dipahami oleh guru-guru setelah sertifikasi. Profesionalisme diartikan sebagai komitmen guru meningkatkan kemampuan profesional secara terus menerus.

Hasil wawancara dengan beberapa kepala Sekolah Dasar Negeri di Kabupaten Lombok Barat dapat disimpulkan bahwa guru yang tersertifikasi sebagian besar masih kurang inisiatif untuk pengembangan keprofesiannya. Setelah memperoleh tunjangan profesi, yang lebih cenderung terlihat adalah pengembangan kebutuhan pribadi, bukan pengembangan kompetensi guna meningkatkan kinerja. Upaya pengembangan diri guru yang tersertifikasi masih kurang dalam beberapa hal seperti: 1) Penggunaan dana tunjangan untuk mengikuti kursus; 2) Pembelian buku penunjang pembelajaran; 3) Pengadaan alat bantu pembelajaran; 4) Keikutsertaan dalam forum ilmiah; 5) Peningkatan pemahaman tentang metode, media, dan teknologi informasi.

Informasi yang diperoleh dari guru yang belum memiliki sertifikat pendidik juga mendukung hasil wawancara dengan kepala sekolah, bahwa belum terlihat jelas dampak sertifikasi terhadap peningkatan kinerja guru yang tersertifikasi. Guru yang tersertifikasi masih ada yang jarang membuat RPP, kesulitan menggunakan komputer, kurang terbiasa membaca jurnal-jurnal ilmiah, guru yang sudah mengikuti pelatihan jarang membagi pengalamannya selama pelatihan kepada rekan guru yang tidak mengikuti pelatihan, dan jarang melakukan penelitian tindakan kelas untuk memecahkan permasalahan dalam pembelajaran di kelas.

Wawancara dengan guru tersertifikasi melengkapi informasi terkait kinerja guru setelah memperoleh sertifikat pendidik. Untuk pengembangan keprofesian, kecenderungan para guru terbiasa menunggu instruksi dari atasan untuk mengikuti pelatihan ataupun melakukan penelitian. Keinginan para guru tersertifikasi menggunakan dana tunjangan untuk mengikuti kursus komputer dan bahasa inggris kurang mendapat dukungan dari kepala sekolah. Guru tersertifikasi yang sering ditunjuk oleh kepala sekolah untuk mengikuti pelatihan pun masih kurang aplikatif untuk membagi pengetahuan yang diperoleh selama pelatihan.

Seharusnya setelah guru memiliki bukti kelayakan dan kemampuan standar sebagai seorang profesional, perilaku yang profesional pun dapat ditunjukkan oleh guru 
sebagai bukti dedikasi dan komitmennya terhadap profesinya. Bukti ini dapat ditunjukkan oleh guru dengan kinerja yang lebih baik dibandingkan dengan guru yang belum memiliki sertifikat. Selain bertanggung jawab terhadap mutu pendidikan melalui kualitas layanan dalam melaksanakan tugas, guru bersertifikat juga harus bertanggung jawab terhadap bukti kelayakan atau sertifikat yang dimiliki.

Selain upaya-upaya pengembangan keprofesian yang dilakukan guru baik secara individual maupun kolektif, pengembangan profesional secara institusional perlu dilakukan guru atas inisiatif kepala sekolah ataupun otoritas pendidikan lainnya. Kepala sekolah di Sekolah Dasar (SD) adalah seorang guru bersertifikat yang diberikan tugas tambahan menjabat sebagai pimpinan di sekolah.

Disamping tugasnya menjadi guru yang juga telah memiliki sertifikat, kepala sekolah memiliki tugas lain yaitu sebagai seorang pemimpin. Kepala sekolah sebagai pemimpin adalah orang yang mampu memotivasi, menggerakkan, dan membimbing para guru yang menjadi bawahannya agar bersama-sama berupaya secara terus menerus untuk meningkatkan kinerja dalam upaya mencapai tujuan pendidikan.

Pada kenyataannya, kepala sekolah belum mampu melakukan pembaharuanpembaharuan yang bermanfaat bagi terciptanya aktivitas pembelajaran yang berkualitas. Disamping tugasnya menjadi guru yang juga telah memiliki sertifikat, kepala sekolah memiliki tugas lain yaitu sebagai seorang pemimpin yang mampu memotivasi, menggerakkan, dan membimbing para guru agar bersama-sama berupaya secara terus menerus meningkatkan kinerja dalam upaya mencapai tujuan pendidikan.
Berdasarkan uraian di atas, penting untuk diungkapkan lebih jauh mengenai kinerja guru setelah sertifikasi. Oleh karena itu, penelitian ini dibatasi pada menelaah variabelvariabel yang berpengaruh terhadap kinerja guru yaitu pengembangan keprofesian dan kepemimpinan kepala sekolah.

Tujuan penelitian ini adalah untuk mengetahui pengaruh pengembangan keprofesian dan kepemimpinan kepala sekolah terhadap kinerja guru baik secara sendirisendiri (parsial) maupun bersama-sama (simultan). Kinerja guru dalam melaksanakan aktivitas pembelajaran dapat dilakukan dengan baik dan maksimal jika guru memiliki pengetahuan, melakukan tugas sesuai pengetahuan yang dimiliki dan mendapat dukungan dari lingkungan tempat guru bekerja. Dengan mengetahui pengaruh pengembangan keprofesian dan kepemimpinan kepala sekolah terhadap kinerja guru, selanjutnya dapat ditentukan strategi pembimbingan guru. Teori tujuan mendalilkan bahwa hubungan yang penting timbul antara tujuan, harapan, atribusi, konsep kemampuan, orientasi motivasi, perbandingan sosial dan diri, dan perilaku berprestasi (Schunk, 2012: 512). Bernadin et al., (Jones, Jenkin dan Lord, 2006: 3) mengartikan performance yaitu "the outcomes of work because they provide the strongest linkage to the strategic goals of the organization, customer satisfaction, and economic contribution".

Menurut Robbins (Supardi, 2013: 47) kinerja (performance) merupakan fungsi dari interaksi antara ability (kemampuan dasar) dengan motivation (motivasi) $\mathrm{P}=(\mathrm{A} \times \mathrm{M})$. Teori kinerja Gibson membagi tiga kelompok variabel yang mempengaruhi perilaku kerja dan kinerja yaitu (Supardi, 2013: 31):

a. Variabel individu, sub-variabel individu 
dikelompokkan pada kemampuan dan keterampilan, latar belakang, dan demografis;

b. Variabel organisasi, sub-variabel dari organisasi digolongkan pada sumber daya, kepemimpinan, imbalan, struktur, dan desain pekerjaan;

c. Variabel psikologis, sub-variabel psikologis terdiri dari persepsi, sikap, kepribadian, belajar, dan motivasi.

Kinerja guru dalam penelitian ini dilihat dari unjuk kerja guru dalam melaksanakan aktivitas pembelajaran yaitu, 1) perencanaan kegiatan pembelajaran yang dilihat dari penyusunan program kegiatan pembelajaran yang dilakukan guru; 2) pelaksanaan kegiatan pembelajaran di kelas meliputi pengelolaan kelas, penggunaan media dan sumber belajar, penggunaan metode serta strategi pembelajaran; 3) penilaian hasil belajar untuk mengetahui tercapai atau tidaknya tujuan pembelajaran dan juga proses pembelajaran yang dilakukan; 4) refleksi diri terhadap masalah yang dihadapi serta kompetensi yang perlu dikembangkan; dan 5) pengembangan keprofesian berkelanjutan.

Teori kebutuhan Maslow yang dikenal dengan hierarki kebutuhan (hierarchy of needs) menjelaskan tentang lima tingkatan kebutuhan manusia. Untuk mencapai tujuan, seseorang melakukan perilaku yang berkesinambungan. Lima tingkatan kebutuhan dalam teori kebutuhan Maslow dimulai dari kebutuhan fisiologi (psysiological needs), kebutuhan keamanan, kebutuhan kebersamaan, kebutuhan keyakinan dan yang terakhir yaitu kebutuhan aktualisasi diri (Schunk, 2012: 482-484). Teori motivasi Alderfer (Alderfer's ERG Theory) juga mengenalkan tiga kelompok kebutuhan, yaitu: 1) kebutuhan akan keberadaan (existence need); 2) kebutuhan keterkaitan (relatedness need); dan 3) kebutuhan pertumbuhan (growth need) (Uno, 2012: 43).

Dari beberapa teori yang dipaparkan sebelumnya, kebutuhan seseorang untuk mengaktualisasikan atau mengembangkan diri perlu dipenuhi dalam upaya mencapai tujuan. Aktualisasi atau pengembangan diri ini dapat ditunjukkan melalui maksimalnya potensi seseorang dengan melakukan pengembangan diri secara berkelanjutan. Pengembangan Keprofesian Berkelanjutan (PKB) adalah bentuk pembelajaran berkelanjutan bagi guru yang merupakan kendaraan utama dalam upaya membawa perubahan yang diinginkan berkaitan dengan keberhasilan siswa (Kemendiknas, 2011: 9).

Saud (2013: 98) mengartikan profesionalisasi dalam bidang keguruan sebagai peningkatan segala daya dan usaha dalam rangka pencapaian secara optimal layanan yang akan diberikan kepada masyarakat. Pengembangan keprofesian dalam penelitian ini diartikan sebagai dorongan guru untuk memelihara dan meningkatkan standar keprofesian. Pemeliharaan dan peningkatan standar keprofesian ini diorientasikan untuk mengoptimalkan layanan pembelajaran yang berkualitas dalam pelaksanaan tugas dan kewajibannya.

Teori sosiologis mendasari konsep kepemimpinan sebagai usaha-usaha untuk melancarkan hubungan dalam organisasi dan sebagai usaha untuk menyelesaikan konflik organisatoris antara para pengikutnya agar tercapai kerja sama yang baik (Kurniadin dan Machali, 2012: 299). Untuk dapat membangkitkan semangat kerja karyawan, faktor motivator yang sifatnya intrinsik (berada dalam diri) perlu diperhatikan untuk dikembangkan antara lain: 1) faktor 
keberhasilan; 2) faktor penghargaan; 3) faktor pekerjaannya sendiri; 4) rasa tanggung jawab; dan 5) faktor peningkatan (Thoha, 2012: 231233).

Yukl (2001: 7) menjelaskan bahwa "Leadership is process of influencing others to understand and agree about what needs to be done and how it can be done effectively, and the process of facilitating individual and collective effort to accomplish the shared objectives".

Kepemimpinan yang dibutuhkan di zaman yang terus berubah ini adalah kepemimpinan yang tetap berorientasi kepada tujuan, namun dengan memperhatikan perubahan situasi yang terjadi di lingkungannya. Hal ini yang mendasari kepemimpinan transformasional digunakan dalam penelitian ini. Sadler (Kurniadin dan Machali, 2012: 317) menjelaskan pengertian kepemimpinan transformatif sebagai proses mengembangkan komitmen pengikut dengan berbagai nilai-nilai dan visi organisasi.

Kepemimpinan kepala sekolah dalam penelitian ini dilihat dari persepsi guru terhadap proses kepala sekolah memotivasi, membimbing, dan memberdayakan semua pihak yang ada di sekolah serta pihak lain yang terkait dengan sekolah agar bekerja sama dalam mencapai tujuan sekolah. Kepemimpinan kepala sekolah dalam penelitian ini dilihat dari empat komponen kepemimpinan transformasional yang dilaksanakan oleh kepala sekolah yaitu: 1) pengaruh ideal (sifat atau tingkah laku); 2) motivasi untuk berprestasi; 3) rangsangan intelektual; dan 4) pertimbangan kepada individu.

\section{METODE PENELITIAN}

\section{Jenis Penelitian}

Penelitianinimenggunakanpendekatan kuantitatif expost facto, yaitu penelitian yang tidak memberikan pengendalian atau perlakuan terhadap variabel bebas secara langsung karena sudah terjadi secara alami dan bertujuan untuk mengetahui ada tidaknya hubungan antara variabel bebas dan variabel terikat.

\section{Waktu dan Tempat Penelitian}

Pengambilan data penelitian dilaksanakan di Sekolah Dasar Negeri SeKecamatan Labuapi Kabupaten Lombok Barat dari bulan November tahun 2014 sampai dengan bulan Juni tahun 2015.

\section{Subjek Penelitian}

Populasi dalam penelitian ini adalah guru Sekolah Dasar Negeri berstatus Pegawai Negeri Sipil (PNS) tersertifikasi sebanyak 187 guru. Teknik sampling yang akan digunakan adalah Simple Random Sampling, sehingga diperoleh sampel sebanyak 66 guru.

\section{Prosedur Penelitian}

Kuesioner dari masing-masing variabel bebas dan variabel terikat dibagikan kepada responden yaitu PNS tersertifikasi.

\section{Teknik Pengumpulan Data}

Instrumen yang digunakan untuk mengukur variabel kinerja adalah kuesioner; variabel pengembangan keprofesian diukur dengan kuesioner dan dokumentasi; variabel kepemimpinan transformasional diukur dengan kuesioner.

\section{Teknik Analisis Data}

Analisis data yang digunakan adalah analisis deskriptif dan analisis inferensial untuk menguji hipotesis, dimana uji prasyarat dilakukan terlebih dahulu sebelum menguji hipotesis. Penyajian pada analisis deskriptif penelitian ini berupa: ukuran tendesi sentral meliputi mean, median dan modus, dan ukuran penyebaran data.

Uji prasyarat yang dilakukan meliputi uji 
normalitas, uji homoskedastisitas dan uji multikolinieritas. Hipotesis pada penelitian ini diuji dengan analisis regresi dan analisis korelasi parsial. Teknik analisis regresi ganda adalah suatau analisis peramalan nilai pengaruh dua variabel bebas atau lebih terhadap variabel terikat untuk membuktikan ada atau tidaknya hubungan fungsi atau hubungan kausal antara dua variabel bebas atau lebih (X1 Kepemimpinan kepala sekolah dalam penelitian ini dilihat dari empat komponen kepemimpinan transformasional yang dilaksanakan oleh kepala sekolah yaitu: 1) pengaruh ideal (sifat atau tingkah laku); 2) motivasi untuk berprestasi; 3) rangsangan intelektual; dan 4) pertimbangan kepada individu.

Analisis korelasi parsial digunakan untuk melihat hubungan variabel terikat dengan sebuah variabel bebas disertai persyaratan sejumlah variabel bebas lain ada dalam keadaan tertentu. Hal ini berarti kita mengontrol sejumlah variabel bebas dan melihat bagaimana kelakuan variabel bebas lainnya dengan variabel terikat.

\section{HASIL PENELITIAN DAN PEMBAHASAN}

\section{Analisis Deskriptif}

Analisis deskriptif bertujuan untuk mendapatkan gambaran keadaan subyek penelitian pada setiap variabel yang diukur. Deskripsi data penelitian ini diperoleh dari hasil analisis deskriptif data yang meliputi nilai maksimum dan minimum, penyajian ukuran tendensi sentral yaitu mean, modus, median, dan ukuran penyebaran (simpangan baku) dari masing-masing variabel yaitu pengembangan keprofesian (X1), kepemimpinan kepala sekolah (X2), kinerja guru (Y). Hasil analisis deskriptif pada penelitian ini disajikan pada
Tabel 1 berikut.

Tabel 1.Analisis Deskriptif Skor Kuesioner Hasil Penelitian

\begin{tabular}{lcccc}
\hline \multicolumn{1}{c}{ Variabel } & Mak & Min & $\overline{\bar{X}}$ & SD \\
\hline $\begin{array}{l}\text { Pengembangan } \\
\text { Keprofesian }\end{array}$ & 84 & 45 & 63,24 & 10,86 \\
$\begin{array}{l}\text { Kepemimpinan } \\
\text { Kepala Sekolah }\end{array}$ & 188 & 114 & 160,91 & 17,78 \\
Kinerja Guru & 140 & 83 & 114,91 & 13,22 \\
\hline
\end{tabular}

Berdasarkan kuesioner pengembangan keprofesian diperoleh rentang skor antara 45 sampai dengan 84; rata-rata (mean) sebesar 63,24; nilai tengah (median) sebesar 63,50; modus sebesar 72; dan simpangan baku sebesar 10,86. Dari data hasil penelitian tersebut, dapat diketahui bahwa pengembangan keprofesian guru setelah sertifikasi secara keseluruhan cukup baik, hal ini dapat dilihat dari hasil perhitungan bahwa rerata data hasil penelitian (empiris) lebih besar dibandingkan rata-rata kriteria. Demikian pula ditinjau dari indikator pengukuran pengembangan keprofesian, $76,2 \%$ telah melaksanakan pengembangan diri, 45,9\% guru PNS bersertifikat telah melakukan publikasi ilmiah, dan 48,6\% guru PNS bersrtifikat telah menghasilkan karya inovatif..

Berdasarkan kuesioner kepemimpinan kepala sekolah diperoleh rentang skor antara 114 dan 188; rata-rata sebesar 160,91; median sebesar 162,50; modus sebesar 173; dan simpangan baku sebesar 17,78, dengan sebaran frekuensi kepemimpinan kepala sekolah di atas rerata $(160,91)$ sebanyak 59,1\%.

Dari data hasil kuesioner tersebut, dapat diketahui bahwa kepemimpinan kepala sekolah berkategori cukup baik, hal ini terlihat dari rata-rata hasil perhitungan (empiris) lebih besar dibandingkan dengan rata-rata kriteria. Jika ditinjau lebih detail dari masing- 
masing indikator kepemimpinan kepala sekolah, 74,76\% kepala sekolah telah menunjukkan pengaruh ideal (sikap dan tingkah laku), 86,44\% kepala sekolah telah menunjukkan motivasi berprestasi, 70,83\% telah memberikan rangsangan intelektual, dan $84,72 \%$ kepala sekolah telah melakukan pertimbangan kepada individu yang ada di sekolah.

Berdasarkan hasil penelitian diperoleh rentang skor antara 83 sampai dengan 140; ratarata (mean) sebesar 114,91; median sebesar 116,50; modus sebesar 125; dan simpangan baku sebesar 13,22, dengan sebaran frekuensi kinerja guru di atas rerata $(114,91)$ sebanyak $54,54 \%$. Dari hasil kuesioner ini menunjukkan bahwa kinerja guru berada pada kategori sangat baik, hal ini ditunjukkan dari nilai ratarata yang diperoleh (empiris) lebih kecil dari rerata kriteria.

\section{UJI HIPOTESIS}

Pengujian hipotesis dilakukan dengan analisis regresi dan analisis korelasi parsial, dengan taraf signifikansi sebesar 0,05 . Sebelum pengujian terhadap hipotesis penelitian menggunakan regresi dan korelasi parsial, maka terlebih dahulu dilakukan analisis mengenai keeratan hubungan dua variabel bebas terhadap variabel terikat dengan analisis korelasi.

Pengujian Pengaruh Pengembangan
Keprofesian Terhadap Kinerja Guru

Rangkuman hasil analisis hipotesis pertama dapat dilihat pada tabel berikut:

Tabel 2. Hasil Analisis Uji Hipotesis Pertama

\begin{tabular}{ccccc}
\hline Variabel Korelasi $t_{\text {hitung }}$ & $\begin{array}{c}\text { Koefisien } \\
\mathrm{R}^{2}\end{array}$ & $\begin{array}{c}\text { Korelasi } \\
\text { Parsial }\end{array}$ \\
\hline$\left(\mathrm{X}_{1}\right)$ & 0,662 & 7,066 & $43,8 \%$ & 0,597 \\
\hline
\end{tabular}

Berdasarkan hasil analisis korelasi menunjukkan tingkat hubungan antara variabel pengembangan keprofesian dengan kinerja guru sebesar 0,662. Koefisien yang bertanda positif ini menunjukkan bahwa pengembangan keprofesian memiliki keeratan hubungan dengan kinerja guru.

Bentuk persamaan regresi dari pengaruh pengembangan keprofesian (X1) terhadap kinerja guru $(\mathrm{Y})$ sebagai berikut: $\mathrm{Y}^{\wedge}=\mathrm{a}+\mathrm{b}_{-1}$ $\mathrm{X}_{-1}=63,923+0,806 \mathrm{X}_{-1}$. Koefisien regresi sebesar 0,806 menyatakan bahwa setiap penambahan (karena tanda + ) satu skor atau nilai pengembangan keprofesian (X1) akan memberikan peningkatan skor sebesar 0,806 pada variabel kinerja guru. Nilai thitung $>$ ttabel atau 7,066 > 2,000 maka Ho ditolak yang artinya koefisien regresi signifikan atau pengembangan keprofesian (X1) benarbenar berpengaruh secara signifikan terhadap kinerja guru. Nilai koefisien determinasi R2 yakni sebesar 0,438 . Hal ini berarti besarnya sumbangan pengembangan keprofesian setelah sertifikasi terhadap kinerja guru sebesar $43,8 \%$, sedangkan sisanya $56,2 \%$ dipengaruhi oleh faktor lain.

Pengujian Pengaruh Kepemimpinan Kepala Sekolah Terhadap Kinerja Guru

Rangkuman hasil analisis hipotesis kedua dapat dilihat pada tabel berikut:

Tabel 3. Hasil Analisis Uji Hipotesis Kedua

\begin{tabular}{lllll}
\hline Variabel Korelasi & thitung $^{\text {Koefisien }}$ & $\begin{array}{c}\text { Korelasi } \\
\mathrm{R}^{2}\end{array}$ & Parsial \\
\hline$\left(\mathrm{X}_{2}\right)$ & 0,430 & 3,811 & $18,5 \%$ & 0,258 \\
\hline
\end{tabular}

Berdasarkan hasil analisis korelasi menunjukkan tingkat hubungan antara variabel pengembangan keprofesian dengan kinerja guru sebesar 0,430. Koefisien yang bertanda positif ini menunjukkan bahwa kepemimpinan 
kepala sekolah memiliki keeratan hubungan dengan kinerja guru.

Bentuk persamaan regresi dari pengaruh kepemimpinan kepala sekolah (X2) terhadap kinerja guru (Y) sebagai berikut: $\mathrm{Y}$ $\hat{\imath}=\mathrm{a}+\mathrm{b}_{-1} \mathrm{X}_{-1}=63,434+0,320 \mathrm{X}_{-2}$. Koefisien regresi sebesar 0,320 menyatakan bahwa setiap penambahan (karena tanda + ) satu skor atau nilai kepemimpinan kepala sekolah (X2) akan memberikan peningkatan skor sebesar 0,320 pada variabel kinerja guru. Nilai thitung $>$ ttabel atau 3,811>2,000 maka Ho ditolak yang artinya koefisien regresi kepemimpinan kepala sekolah (X2) signifikan atau benarbenar berpengaruh secara signifikan terhadap kinerja guru. Nilai koefisien determinasi R2 yakni sebesar 0,185 . Hal ini berarti besarnya sumbangan pengembangan keprofesian setelah sertifikasi terhadap kinerja guru sebesar $18,5 \%$, sedangkan sisanya $81,5 \%$ dipengaruhi oleh faktor lain.

Pengujian Pengaruh Pengembangan Keprofesian dan Kepemimpinan Kepala Sekolah Terhadap Kinerja Guru

Rangkuman hasil analisis hipotesis ketiga dapat dilihat pada tabel berikut:

Tabel 4. Hasil Analisis Uji Hipotesis Ketiga

\begin{tabular}{lccc}
\hline Variabel & Korelasi & F $_{\text {hitung }}$ & $\begin{array}{c}\text { Koefisien } \\
\mathrm{R}^{2}\end{array}$ \\
\hline$\left(\mathrm{X}_{1}, \mathrm{X}_{2}\right)-\mathrm{Y}$ & 0,380 & 28,568 & $47,6 \%$ \\
\hline
\end{tabular}

Berdasarkan hasil analisis korelasi menunjukkan tingkat hubungan antara variabel pengembangan keprofesian dan kepemimpinan kepala sekolah dengan kinerja guru sebesar 0,380. Koefisien yang bertanda positif ini menunjukkan bahwa pengembangan keprofesian dan kepemimpinan kepala sekolah memiliki keeratan hubungan dengan kinerja guru.
Bentuk persamaan regresi dari pengaruh pengembangan keprofesian (X1) dan kepemimpinan kepala sekolah (X2) terhadap kinerja guru $(\mathrm{Y})$ sebagai berikut $\mathrm{Y}^{\wedge}=\mathrm{a}+\mathrm{b}_{-1}$ $\mathrm{X}_{-1} \mathrm{~b}_{-2} \mathrm{X}_{-2}=45,032+0,710 \mathrm{X}_{-} 1+0,155 \mathrm{X}_{-2}$. Persamaan garis regresi yang positif ini mengindikasikan bahwa semakin baik pengembangan keprofesian guru setelah sertifikasi dan semakin baik kepemimpinan kepala sekolah, maka kinerja guru akan meningkat.

Nilai Fhitung $>$ Ftabel atau 28,568 $>3,13$ membuktikan bahwa pengembangan keprofesian dan kepemimpinan kepala sekolah berpengaruh terhadap kinerja guru. Nilai R Square sebesar 0,476 berarti bahwa variabel pengembangan keprofesian $\left(\mathrm{X}_{1}\right)$ dan variabel kepemimpinan kepala sekolah $\left(\mathrm{X}_{2}\right)$ berpengaruh terhadap kinerja guru sebesar $47,6 \%$, dan sisanya sebesar $52,4 \%$ ditentukan oleh sebab lain yang tidak diteliti.

Pembahasan

Tujuan umum penelitian ini adalah untuk memperoleh gambaran tentang pengaruh pengembangan keprofesian (X1) dan kepemimpinan kepala sekolah terhadap kinerja guru $(\mathrm{Y})$ baik secara individu (parsial), maupun secara bersama-sama (simultan). Hasil penelitian menunjukkan bahwa: 1) pengembangan keprofesian berpengaruh terhadap kinerja guru; 2) kepemimpinan kepala sekolah berpengaruh terhadap kinerja guru; dan 3) pengembangan keprofesian dan kepemimpinan kepala sekolah berpengaruh terhadap kinerja guru.

kinerja memiliki arti sebagai unjuk kerja yang ditampilkan seseorang. Banyak faktor yang mempengaruhi kinerja guru dalam melaksanakan aktivitas pembelajaran. Pada penelitian ini, faktor tersebut dibatasi pada pengembangan keprofesian dan kepemimpinan 
kepala sekolah. Berdasarkan hasil analisis dari data penelitian, pengaruh masing-masing variabel baik secara parsial maupun simultan dapat dibahas sebagai berikut:

Pengaruh Pengembangan Keprofesian (X1) Terhadap Kinerja Guru (Y)

Hasil uji hipotesis menunjukkan bahwa pengembangan keprofesian guru setelah sertifikasi diindikasikan dengan adanya: 1) pengembangan diri guru melalui ikut serta dalam diklat fungsional dan kegiatan kolektif; 2) publikasi ilmiah yang diindikasikan melalui presentasi pada forum ilmiah, publikasi ilmiah hasil penelitian, publikasi buku teks pelajaran dan pedoman guru; 3) karya inovatif guru melalui penemuan teknologi tepat guna, penemuan/penciptaan karya seni, pembuatan/ pemodifikasian alat pelajaran/alat peraga, dan penyusunan pedoman/soal mampu mempengaruhi kinerja guru.

Pengembangan keprofesian guru setelah sertifikasi lebih mempermudah guru dalam melaksanakan aktivitas pembelajaran. Guru professional yang senantiasa memelihara dan meningkatkan pengembangan keprofesiannya menjadikan mengajar dan mendidik sebagai ladang untuk mencetak generasi penerus bangsa yang cerdas, berbudi pekerti luhur, kreatif dan inovatif dalam menghadapi perkembangan ilmu pengetahuan. Pengembangan keprofesian guru setelah sertifikasi dapat dijelaskan melalui kajian teori kebutuhan Maslow yang dikenal dengan hierarki kebutuhan. Lima tingkatan hierarki kebutuhan Maslow menunjukkan kesinambungan perilaku seseorang dalam memenuhi kebutuhan dimulai dengan terpenuhinya kebutuhan fisiologi, kebutuhan keamanan, kebutuhan kebersamaan, kebutuhan keyakinan, dan kebutuhan aktualisasi diri (Schunk, 2012: 482-484).

Melalui sertifikasi, pemenuhan terhadap kebutuhan keyakinan guru terpenuhi. Selanjutnya untuk mencapai tingkatan tertinggi yaitu kebutuhan mengaktualisasikan diri dapat diwujudkan guru dengan melakukan pertumbuhan atau pengembangan keprofesian. Hasil penelitian yang dilakukan oleh Althauser (2015) mendukung penelitian ini menjelaskan bahwa program pengembangan keprofesian dapat meningkatkan pemberdayaan diri guru dan prestasi siswa. Pemberdayaan diri guru secara pribadi dan umum melalui partisipasi pada program pengembangan keprofesian memiliki hubungan untuk meningkatkan prestasi siswa sesuai dengan tujuan dari pengembangan keprofesian adalah untuk meningkatkan prestasi siswa.

Berdasarkan kajian di atas dapat ditarik kesimpulan bahwa guru-guru yang telah disertifikasi dan berusaha untuk melakukan pengembangan keprofesian akan memberikan dampak baik pada kinerja guru. Penghargaan yang diperoleh guru melalui sertifikasi dapat dimaknai oleh guru dengan melakukan pengembangan keprofesian sebagai salah satu upaya mememlihara dan meningkatkan kualitas layanan pendidikan yang baik bagi siswa.

Pengaruh Kepemimpinan Kepala Sekolah (X2) Terhadap Kinerja Guru (Y)

Hasil uji hipotesis menunjukkan bahwa kepemimpinan kepala sekolah berpengaruh terhadap kinerja guru diindikasikan melalui pengaruh ideal (sikap dan tingkah laku), rangsangan intelektual, motivasi berprestasi, dan pertimbangan kepada individu yang dimiliki oleh kepala sekolah. Menurut teori tersebut, agar para karyawan bisa termotivasi 
mereka hendaknya mempunyai suatu pekerjaan dengan isi yang selalu merangsang untuk berprestasi (Thoha, 2012: 231-333). Kepala sekolah yang profesional senantiasa berupaya untuk memberikan layanan yang terbaik bagi para guru yang dipimpinnya.

Aspek pengukuran kepemimpinan kepala sekolah dalam penelitian ini terdiri dari empat dimensi yaitu pengaruh ideal (sikap dan tingkah laku), rangsangan intelektual, motivasi berprestasi, dan pertimbangan kepada individu. Aspek pengukuran ini sebagai penjelas dari usaha kepala sekolah memotivasi guru dalam upaya peningkatan kinerja. Hasil penelitian ini menunjukkan bahwa melalui keempat aspek tersebut kepala sekolah mampu memotivasi, membimbing, dan memberdayakan semua pihak yang ada di sekolah agar bekerja sama dalam mencapai tujuan sekolah.

Temuan penelitian ini sesuai dengan pendapat Kurniadin dan Machali (2012: 291) bahwa kepemimpinan pendidikan adalah proses mempengaruhi semua personel yang mendukung pelaksanaan aktivitas pembelajaran dalam rangka mencapai tujuan pendidikan. Lebih lanjut Suharsaputra (2013: 135) menjelaskan bahwa kepemimpinan transformasional mempunyai visi yang memotivasi dan menginspirasi anggota organisasi untuk mentransformasikan diri berkinerja lebih baik dalam konteks perubahan yang terjadi.

Hasil penelitian ini juga sejalan dengan pendapat Prasetyo (2006) bahwa untuk menghadapi paradigma baru pendidikan di Indonesia diperlukan pengelolaan yang bermutu. Kepala sekolah sebagai pemimpin di sekolah harus mampu beradaptasi dengan perubahan lingkungan dan mengupdate informasi pendidikan sebagai bahan acuan untuk mempersiapkan arah yang lebih baik di masa depan.

Berdasarkan uraian di atas, dapat disimpulkan bahwa kepemimpinan kepala sekolah memberikan makna yang berarti bagi peningkatan kinerja guru di sekolah. Motivasi yang diberikan oleh kepala sekolah kepada guru menambah keyakinan guru untuk terus berprestasi dan memberikan layanan yang terbaik bagi siswa.

Pengaruh Pengembangan Keprofesian (X1) dan Kepemimpinan Kepala Sekolah (X2) Terhadap Kinerja Guru (Y)

Hipotesis alternatif menunjukkan bahwa pengembangan keprofesian dan kepemimpinan kepala sekolah berpengaruh terhadap kinerja guru Sekolah Dasar seKecamatan Labuapi Kabupaten Lombok Barat. Hasil ini dapat dimaknai bahwa pengembangan keprofesian dan kepemimpinan kepala sekolah memiliki arti dalam peningkatan kinerja guru. Hasil penelitian lain yang dilakukan Pusat Penelitian Kebijakan, Badan Penelitian Pengembangan Kemendiknas (2010) secara umum menyatakan bahwa kompetensi dan komitmen kerja guru, iklim sekolah, kepemimpinan dan perilaku manajerial kepala sekolah dengan kinerja guru memiliki hubungan yang signifikan (positif).

Tuntutan guru di era sekarang ini menjadi sebuah tantangan tersendiri bagi guru. Perubahan teknologi dan informasi saat ini semakin berkembang, tentunya hal ini berdampak bagi dunia pendidikan. Perubahan yang terjadi mau tidak mau akan menuntut guru agar mau melakukan perubahan melalui pengembangan keprofesiannya.

Selain melalui sertifikasi, motivasi yang dibutuhkan guru juga dapat diperoleh dari pimpinannya di sekolah. Melalui 
kepemimpinannya inilah kepala sekolah mendukung dan memberdayakan potensi guru secara maksimal untuk menunjukkan kinerja yang maksimal. Seyogianya kepala sekolah dapat menyesuaikan kepemimpinannya dengan tuntutan zaman, yaitu pemimpin yang tetap berorientasi pada tujuan dengan memperhatikan perubahan yang terjadi disekitarnya.

Berbagai hal yang perlu ditingkatkan oleh kepala sekolah adalah mengembangkan diri dengan meningkatkan kualifikasi pendidikan, mengkaji permasalahan pendidikan khususnya kepemimpinan pendidikan melalui jurnal-jurnal ilmiah, dan aktif mengikuti Diklat kepemimpinan kepala sekolah.

\section{SIMPULAN DAN SARAN}

Simpulan

Berdasarkan hasil analisis data dan pembahasan yang telah diuraikan, dapat disimpulkan bahwa pengembangan keprofesian berpengaruh terhadap kinerja guru Sekolah Dasar Negeri se-Kecamatan Labuapi Kabupaten Lombok Barat. Nilai t hitung $>\mathrm{t}$ tabel atau 7,066 > 2,000, dengan koefisien determinasi sebesar 43,8\%, dan koefisien korelasi parsial sebesar 0,597 dimaknai bahwa pengembangan keprofesian yang dilakukan guru setelah sertifikasi dapat mempengaruhi kinerja guru. Semakin baik atau meningkatnya profesionalisme guru bersertifikat dalam menjalankan tugas maka kinerja guru akan meningkat.

Pengaruh kepemimpinan kepala sekolah yang dinilai berdasarkan persepsi guru terhadap kepemimpinan kepala sekolah berpengaruh terhadap kinerja guru. nilai $\mathrm{t}$ hitung $>\mathrm{t}$ tabel atau 3,811 > 2,000, dengan koefisien determinasi sebesar 18,5\%, dan koefisien korelasi parsial sebesar 0,285. Hal ini dimaknai bahwa kepemimpinan kepala sekolah dapat mempengaruhi kinerja guru. Semakin baik atau meningkatnya fungsi kepemimpinan kepala sekolah, maka kinerja guru meningkat.

Demikian pula dengan pengembangan keprofesian dan kepemimpinan kepala sekolah yang berpengaruh terhadap kinerja guru. Nilai $\mathrm{F}$ hitung $>$ Ftabel atau 28,568 > 3,13 dan koefisien determinasi (R Square) sebesar 47,6\%. Hal ini dimaknai bahwa jika terjadi peningkatan pada pengembangan keprofesian yang dilakukan guru setelah sertifikasi dan peningkatan pada fungsi kepemimpinan kepala sekolah, maka kinerja guru meningkat. Hasil penelitian ini berimplikasi pada pentingnya meningkatkan kinerja yaitu melalui pengembangan keprofesian setelah sertifikasi dan peningkatan fungsi kepemimpinan kepala sekolah..

\section{SARAN}

Kinerja guru dapat ditingkatkan melalui pengembangan keprofesian dan kepemimpinan kepala sekolah. Hal ini dapat dilakukan dengan cara guru aktif melakukan pengembangan keprofesian dan juga mendapatkan dukungan dari kepala sekolah dalam menjalankan tugas keprofesiannya.

\section{DAFTAR PUSTAKA}

Althauser, K.

2015. "Job-embedded professional development: its impact on teacher self-efficacy and student performance". Dalam Teacher Development: An International journal of teachers' professional development. [Online], Vol 19 (2), halaman 210-225. Tersedia: http://dx.doi.org/10.1080/13664530.20 
15.1011346. Diakses pada 28 Juni 2015. Ayal, J.

2013, 27 September. Kemdikbud Akui Kualitas Guru Masih Rendah. Antara News.Com [Online]. 1 halaman. Tersedia: http://m.antaranews.com/ berita/397722/kemdikbud-akui-kualitasguru-masih-rendah. Diakses pada hari Sabtu, 4 April 2015.

Balitbang.

2010. Perbandingan Kinerja Guru Bersertifikat dan Belum Bersertifikat. [Online]. 4 halaman. Tersedia: http:// sippendidikan.kemendikbud.go.id: Diakses pada 21 September 2014. Jones, J., Jenkin, M., \& Lord, S.

2006. Developing Effective Teacher Performance. London. Paul Chapman Publishing. http://Jeff_Jones,_Mazda Jenkin,_Sue_Lord_Developing Effective_Teacher_Performance_2006. pdf. Diakses pada 20 Maret 2015.

Kemendiknas.

2008. Peraturan Pemerintah Republik Indonesia Nomor 74 Tahun 2008 Tentang Guru.

2011. Pedoman Pengelolaan Pengembangan Keprofesian Berkelanjutan (PKB). Direktorat Jenderal Peningkatan Mutu Pendidik dan Tenaga Kependidikan. Buku 1 Pedoman Pengelolaan PKB.pdf. www. bermutuprofesi.org.

Kurniadin, D. dan Machali, I.

2012. Manajemen Pendidikan: Konsep \& Prinsip Pengelolaan Pendidikan. Jogjakarta: AR-RUZZ MEDIA.
2006. "Kepemimpinan di Sekolah Dalam Menghadapi Paradigma Baru Pendidikan di Indonesia". Dalam Manajemen Pendidikan [Online], No.1/ Th.II, halaman 72-83. Tersedia: http:// journal.uny.ac.id/index.php/jmp/article/. Diakses pada 26 Juli 2015.Saud, S. U,. 2013. Pengembangan Profesi Guru. Bandung: Alfabeta.

Suchnk, H. D, .

2012. Learning Theories An Educational Perspective (Teori-teori Pembelajaran: Perpektif Pendidikan. Yogyakarta. Pustaka Pelajar.

Suharsaputra, U.

2013. Administrasi Pendidikan. Bandung. PT Refika Aditama.

Supardi.

2013. Kinerja Guru. Jakarta: PT RajaGrafindo Persada.

2013. Sekolah Efektif: Konsep Dasar dan Praktiknya. Jakarta. Rajawali Pers.

Thoha, $\mathrm{M}$.

012. Perilaku Organisasi. Jakarta: PT RajaGrafindo Persada.

Uno, B. H,

2012. Teori Motivasi \& Pengukurannya: Analisis Di Bidang Pendidikan. Jakarta: Bumi Aksara.

Yukl, G.

2001. Leadership in Organization (Fifth Ed.). New Jersey: Prentice Hall.

Prasetyo, I. 